\title{
The Cultivation of Translation Competence in College English Teaching
}

\author{
Yulou Liu \\ School of Languages and Literature \\ Harbin Institute of Technology, Weihai \\ Weihai, P.R.China
}

\author{
Yingjun Yan \\ School of Languages and Literature \\ Harbin Institute of Technology, Weihai \\ Weihai, P.R.China
}

\author{
Dan Wang \\ School of Languages and Literature \\ Harbin Institute of Technology, Weihai \\ Weihai, P.R.China
}

\begin{abstract}
College English is a compulsory basic course for non-English majors in institutions of higher education. Consequently, College English Teaching becomes an integral component of higher education. The changes in College English Test --- Band 4 and Band 6, such as the appearance of translation in the assessment, together with the improvements in the teaching materials used in college English teaching, for example, the emergence of translation theories and translation practice in the English teaching materials, pose new requirements for college English teaching. The deficiency of college non-English majors in translation demands the joint effort of the college, the teaching faculty and the students to improve translation competence and to adapt to the changes of social development.
\end{abstract}

Keywords-college English teaching; translation competence; cultivation of translation competence

\section{INTRODUCTION}

College English is a compulsory basic course for nonEnglish majors in institutions of higher education. Consequently, College English Teaching becomes an integral component of higher education. A wide variety of teaching materials have been used in teaching college English, but they have a lot of things in common when the preface is carefully review. Now four sets of teaching materials will be discussed for illustration. New College English, edited by Zhejiang University, published by Foreign Language Teaching and Research Press (FLTRP for short) in 2000, writes in its preface that there are all kinds of activities like reading, listening, speaking, writing and translating around one particular theme, with the aim to cultivate the comprehensive abilities of the students to use the language in their daily life. New College English (Integrated Course), published by Shanghai Foreign Languages Education Press (SFLEP for short) in 2001, discusses the purpose to lay a solid foundation for the students' language use and to strengthen their overall English competence through different forms of in-class activities and practices after class, such as reading. Listening, speaking, writing and translating. New College English (the Second Edition), edited by Zhejing University, published by
FLTRP in 2005, emphasizes that various translation techniques have been skillfully integrated into every unit, and that the examples to illustrate these translation techniques have been mainly chosen from the English teaching textbooks. New Horizon College English (the Third Edition), published by FLTRP in 2015, designs a column especially for translation, and its test bank is really rich and comprehensive, covering all types of testing questions, such as listening, speaking, reading, writing and translating.

From these four sets of teaching textbooks, it can be clearly seen that the cultivation and enhancement of translation competence has been placed on a very essential place in college English teaching. In these four textbooks, translation has been mentioned, but with different focus. From the perspective of the change and development of the teaching textbooks, the translation techniques and its application have been paid more and more attention to, and as a result, there emerges the cultivation and improvement of college English teaching.

From the four sets of teaching materials listed above, it can be inferred that the cultivation and improvement of translation ability has been put on an extremely important place in college English teaching. When these four sets of teaching materials are carefully studied, translation has been mentioned in these materials, only with different focuses. From the perspective of the change and development of the teaching materials, translation techniques and their application in reality have been paid more and more attention to. As a consequence, college English teaching is emphasizing the cultivation and enhancement of translation abilities of the students who do not major in English, and therefore this puts forwards new corresponding demands and change for the teachers, as well as the students themselves.

\section{THE COMPARISON BETWEEN THE FOUR SETS OF TEACHING MATERIALS}

New College English, published by FLTRP in 2000, New College English (Integrated Course), published by SFLEP in 
2001, New College English (the Second Edition), published by FLTRP in 2005, and New Horizon College English (the Third Edition), published by FLTRP in 2015, are the four teaching materials commonly used by universities in China in their college English teaching. The deliberate study of these four teaching materials reveals that every one of them has very unique characteristics in the design and practice of translation techniques, which suggests the emphasis of modern college English on the cultivation of translation capabilities.

Based on the previous teaching materials, these four sets have different degrees of improvement and change. There are twelve units in New College English, published by FLTRP in 2000, and every unit is composed of four parts, with each one being Preparation, Listening-Centered Activities, ReadingCentered Activities, and Further Development. Every unit has one centered special theme, around which all kinds of activities like reading, listening, speaking, writing and translating have been designed and organized, with the aim to cultivate the comprehensive abilities of the students to use the language in their daily life. New College English (Integrated Course), published by SFLEP in 2001, has eight units altogether, and everyone is also made up of four parts, being Pre-reading Task, Text A, Text B, and Theme-related Language Learning Tasks respectively, aiming to lay a solid foundation for the students' language use and to strengthen their overall English competence through different forms of activities and practices, for example, the teachers" "elaborate illustration" and the students" "thorough practice". There are ten units in New College English (the Second Edition), published by FLTRP in 2005, and each one of them consists of four parts, including Preparation, Reading-Centered Activities, Further Development, Writing and Translation. In this book, some practices have been renewed, and the cultivation and the enhancement of language application abilities have been put more emphasis on. New Horizon College English (the Third Edition), published by FLTRP in 2015 has eight units, and there are four parts in each unit, to be exact, Preview, Section A, Section B and Unit Project. And especially in Section A, the tasks are Pre-reading activities, Reading comprehension, Language focus, Structure analysis and writing, Translation. In these four sets of teaching materials, what is in common is that all kinds of language activities, such as listening, speaking, reading, writing and translating, are designed and organized around one theme, and that their purpose is to solidify the language basis of the students, and to improve their language application abilities. But on the other hand, what is different is that the design and arrangement of these translation practices are not the same in different teaching materials. New College English, published by FLTRP in 2000, emphasizes English-Chinese translation in the practice, with the title of the exercise being Find the Best Translator. New College English (Integrated Course), published by SFLEP in 2001, puts more emphasis on ChineseEnglish translation, focusing on the usage of the words, phrases, sentence structures that have been learned in the unit, with the title of the excise being Translate the following passage into English, using the words and phrases given below. There is a great change in the translation practice in New College English (the Second Edition), published by FLTRP in 2005. First, this set of textbooks introduces translation theories, and then discusses the translation techniques, with the analysis of the examples that have appeared in the unit. And on this basis, the translation exercises have been arranged with very certain purposes, and it consists of two parts, knowing about translation, and translation practice. New Horizon College English (the Third Edition), published by FLTRP in 2015, covers both English-Chinese and Chinese-English translation, and it turns its focus to the translation of paragraphs, checking the understanding and expression of a much larger translation unit. At the same time, these paragraphs are closely related to the main topic of the unit.

From these teaching materials, it can be seen that translation has been considered as an essential part and been integrated into college English teaching. And yet the fact is that the present translation teaching for non-English majors is not satisfying.

\section{THE DEFICIENCY OF NON-ENGLISH MAJORS' TRANSLATION COMPETENCE}

China gets in closer and closer touch with the whole world, and there are significant changes in College English Tests Band-4, Band-6. In this circumstance, college English teaching and the students themselves have already realized these changes and the consequences they have brought about. English learning puts much emphasis on the all-around development of the students' abilities, such as listening, speaking, reading, writing and translating. Contrary to this emphasis, translation has not been paid enough attention to before in almost every form of assessments. For instance, in Old Band-4 and Band- 6 tests, there was no translation. Different from this, the new Band- 4 and Band- 6 tests include translation in their assessment, with the hint that translation is of great significance for the students.

In the teaching practice, I have a clear awareness that the students have little knowledge about translation and that they are very bad at translating. There are many problems related to their translation. To be exact, in Chinese-English translation, the expression does not conform to the English grammatical habits. In English-Chinese translation, the expression is not faithful, not expressive, and not fluent. In order to fully understand this situation, open-ended questions have been designed to collect information. The investigation into the students I have been teaching has been conducted online, and the results have been summarized and analyzed. The results have shown that various reasons lead to the deficiency of nonEnglish majors' translation competence.

\section{A. The Social Orientation}

There is a kind of orientation in the whole society, that is, if one person learns mathematics very well, he is not afraid to go anywhere. This kind of thinking is so deeply rooted in the society nowadays that the college students cannot turn around this situation. Many students have expressed similar opinions. They chose to study sciences in their high school, and had been greatly influenced by this way of thinking. Their English study and their understanding of English remained just on the level of doing exercises talked about by the teachers. Another very important factor is that the assessment form of College 
Entrance Examination is answering questions. Under these circumstances, the students do not pay attention to other aspects of English learning, not to mention the translation which has never appeared in College Entrance Examination.

\section{B. The Learning Environment}

The students are studying in an environment where the Chinese language is dominant. Basically speaking, English classes are the main opportunity for the students to contact with English. Of course, there are other times when students engage in English, such as watching English movies. But to tell the truth, this is far from enough for learning a language, and our students cannot change this fact. For the students, the limited language input is an extremely serious problem, which is also the difficult situation that the English teaching in China is confronted with. It is difficult for the students to get in touch with foreign teachers or English resources from other sources. The language resources for the students are textbooks required by the study and English films occasionally seen. The limited language input has affected their improvement of language competence to a great extent, with the translation competence not fully emphasized being more serious.

\section{The Learning Objective}

The objective of learning English is to take part in examinations required as it has been before. Many students think that they lose their learning objective all of a sudden after going to college. In the past, they strive for "College Entrance Examination", while the entire change of learning environment leads to their loss in the English study. It is often emphasized that English is important and that learning English well is of great significance, but all this is too far away from the everyday life of the students themselves. The objective of English learning is unclear, and there is no translation in the assessment, so why do they bother to study translation themselves? The form and the content of the assessment influence the habit and the attitude of the students to learn English.

\section{The Students Themselves}

The main factor is the students themselves. Many students admit that they have no strong self-control. Seldom do they study English and materials related to English after class. Their English remains at the level when they are taught by their teachers in their high school. Now in college they just do some choices and they do not consider learning translation knowledge.

There is many a factor that explains why college students who do not specialize in English lack translation competence. Factors, such as the orientation in the society, English learning environment in the Chinese context, the characteristics of the assessment form and content, the learning focus and attitude of the students themselves, account for the shortage of the translation ability for non-English majors in college. Now at present, the society is changing, and the examination system is changing as well. These changes and developments demand that the English teachers and the English learns should reform their ideas and learn English from the requirements of the reality, with the aim to improve their translation ability in their English learning process.

\section{The CUltivation OF TRANSLATION COMPETENCE IN COLLEGE ENGLISH TEACHING}

The reform of the existing examination system and the assessment content, and the social demand for the students' translation competence, put forward new requirements for college English teaching. At the same time, the deficiency of the translation ability of the college students who do not major in English, asks the college English teaching to make a change based on the present situation of the students. For non-English majors in college, they have English classes four hours one week, during which they are required to take part in many activities and practice English skills such as listening, speaking, reading, writing and translating. As a result, how to introduce the translation theories and translation techniques in the limited time, and to improve their translation competence, are what the English teaching is faced with at present. The cultivation of translation competence needs the joint effort of the school, the teachers, and the students to work together, and the translation teaching should start from the teaching practice, and in the meanwhile the teaching in class needs to be adjusted appropriately.

\section{A. Integrating the Translation Theory into In-class Teaching}

It is advised to introduce the translation theory in teaching translation in college English, which follows the principle that the theory guides the practice. "The guidance of the translation theory lies in reducing the ambiguity of the practice and in improving its efficiency". (Liu Miqing, 2003). The students know little about translation, and they know even less the translation theory. In this situation, the translation theory helps to clarify some misunderstandings in their learning of English and the translation. In this way, the students are able to have a correct understanding of translation, and as a consequence this correct understanding makes it possible for the students to form a rational learning attitude and an effective learning method. For instance, faithfulness, expressiveness, and elegance are considered as the criteria of the translation. Then it is beneficial for the students to understand in what way the translated text can be faithful to the original text. The discussion of domestication and foreignization in translation contributes to the understanding of the cultural conflict and thus the students can better deal with the hard problems brought about by this cultural conflict. The division method, which belongs to the category of the translation techniques, helps the students to comprehend and hand long sentences and their translation with more confidence. The translation theory can guide the translation practice of the students to a certain extent, and in turn the students are capable of deepening their understanding of the translation theory and of applying the translation theory more skillfully in their own practice. As a result, the students can improve their translation competence step by step. 


\section{B. Elaborating the Translation Techniques with Concrete Examples}

The translation theory is able to clarify the misunderstanding of the students on a cognitive level, but the improvement of actual translation competence relies on the translation practice guided by the translation techniques. New College English (the Second Edition), published by FLTRP in 2005 , not only briefly introduces the basic theories, but also lists different translation techniques in various contexts. The examples range from words and phrases to short sentences and long sentences. The vivid examples make the abstract theory rich and solid, and at the same time these varied examples reflect the use of the translation techniques. The translation techniques are talked about in class on purpose so that the students are able to understand and make proper use of these techniques that have been learned in class. In the first unit of New College English (the Second Edition) (Book Three), published by FLTRP in 2005, The Translation of the Passive Voice is introduced, which, for the students, is not only the summary and review of the English grammatical knowledge, but also is a comparison between the English and the Chinese languages in use of voices. As is concluded in this section, comparatively speaking, the passive structure in the Chinese language is much less often used, and its passive meaning is conveyed through the active forms. As a result, in the EnglishChinese translation, this difference needs to be paid more attention to in order to translate the English sentences into more idiomatic Chinese. The learning of translation can be furthered by comparison, and the translation competence is expected to be enhanced under the guidance of the translation techniques.

\section{CONCLUSION}

The translation competence is related to the comprehension and mastery of the English knowledge, and in the meanwhile it is related to the understanding capacity and the expressive level of both the Chinese and the English languages of the students. Therefore, the cultivation and enhancement of the translation competence needs greater effort, such as to cultivate the students' sensing capability of the language, to improve their appreciative level of the language, to enhance their cultural accomplishment and so on. The society is changing quickly. In this very particular situation, integrating the translation teaching into the college English teaching for the college students who do not major in English, helps the students to cope more skillfully and confidently with the changes brought about by the assessment form, and also improves the teaching quality, thus satisfying the demand of the society for the college students in every aspect and enhancing the students' overall capacity to apply the English language they have been studying all the way.

\section{REFERENCES}

[1] Jin Fang. On the Enhancement of the Translation Competence of NonEnglish Majors in College [J]. Journal of Wuhan University of Science and Technology (Social Sciences Edition). 2003(5).
[2] Li Yinhua, Wang Deming, Xia Guozuo, Yu Jianzhong (Editors in chief). New College English (Integrated Course) [M]. Shanghai: Shanghai Foreign Languages Education Press. 2001.

[3] Liu Miqing. On the Technique Awareness of the Translator. Chinese Translators Journal [J]. 2003 (5)

[4] Xiong Li. The Translation Teaching and the College English Teaching Reform [J]. Journal of Shaoyang College (Social Sciences Edition). $2005(03)$.

[5] Ying Huilan (Editor in chief). New College English [M]. Beijing: Foreign Language Teaching and Research Press. 2000.

[6] Ying Huilan (Editor in chief). New College English (the Second Edition) [M]. Beijing: Foreign Language Teaching and Research Press. 2005.

[7] Zheng Shutang (Editor in chief). New Horizon College English (the Third Edition) [M]. Beijing: Foreign Language Teaching and Research Press. 2015

[8] Liu Xiaomin, Liu Jinlong. College English Translation Teaching: the Problems and their Solutions [J]. Shandong Foreign Languages Research. 2013 (5).

[9] Kang Lixin. The Reflection on College English Translation Teaching: Based on the Comparative Analysis of the Teaching Syllabus [J]. Heilongjiang Researches on Higher Education. 2014 (8).

[10] Ye Feng. Analysis on the College English Translation Teaching Strategy from the Perspective of Chunk Theory [J]. Journal of the Chinese Society of Education. 2015 (2).

[11] Wang Yuxi. Reflection on College English Translation Teaching [J]. Chinese Translators Journal. 2010 (6).

[12] Luo Xuanmin, Shao Youxue. On the Composition of College English Translation Teaching Materials: Taking New Era Interactive English (Reading, Writing, and Translating, Book 1-4) [J]. Foreign Languages and THEIR Teaching. 2009 (11). 